\title{
PENGARUH PEMBERIAN KOMBINASI JENIS DAN DOSIS PUPUK ORGANIK TERHADAP PERTUMBUHAN DAN HASIL BAWANG MERAH (Allium ascalonicum L.)
}

\section{THE EFFECT OF GIVING A COMBINATION OF TYPES AND ORGANIC FERTILIZER DOSES ON THE GROWTH AND YIELD OF SHALLOTS (Allium ascalonicum L.)}

\author{
Rudi Priyadi ${ }^{1}$, Dedi Natawijaya ${ }^{1}$, Rida Parida ${ }^{1}$, Ade Hilman Juhaeni ${ }^{1}$ \\ ${ }^{1}$ Program Studi Agroteknologi Fakultas Pertanian Universitas Siliwangi \\ Jalan Siliwangi No.24 Kota Tasikmalaya Kode Pos 46115 Jawa Barat \\ Korespondensi : rudipriyadi@unsil.ac.id
}

\begin{abstract}
ABSTRAK
Salah satu cara untuk meningkatkan hasil bawang merah dengan teknik budidaya adalah melakukan pemupukan. Pemupukan merupakan pemberian pupuk guna menambah persediaan unsur hara yang dibutuhkan oleh tanaman dalam upaya meningkatkan hasil dan mutu hasil tanaman. Tujuan penelitian ini yaitu untuk mendapatkan kombinasi jenis dan dosis pupuk organik yang berpengaruh paling baik untuk pertumbuhan dan hasil tanaman bawang merah (Allium ascalonicum L.). Penelitian dilaksanakan pada bulan Februari sampai bulan April 2021 di Kebun Percobaan Fakultas Pertanian Universitas Siliwangi Kelurahan Mugarsari Kecamatan Tamansari, Kota Tasikmalaya pada ketinggian 374 meter di atas permukaan laut. Penelitian ini menggunakan metode eksperimen dengan Rancangan Acak Kelompok (RAK) yang terdiri dari 7 perlakuan dan diulang sebanyak 4 kali yaitu, $\mathrm{P} 0=$ kontrol (tanpa pupuk organik), $\mathrm{P} 1=$ pupuk organik kotoran kambing $10 \mathrm{t} \mathrm{ha}^{-1}, \mathrm{P} 2=$ pupuk organik kotoran ayam $10 \mathrm{tha}^{-1}, \mathrm{P} 3=$ pupuk organik kotoran kambing 20 ton/ha, $\mathrm{P} 4=$ pupuk organik kotoran ayam $20 \mathrm{t} \mathrm{ha}^{-1}, \mathrm{P} 5=$ pupuk organik kotoran kambing $5 \mathrm{t}^{\mathrm{a}} \mathrm{a}^{-}$ ${ }^{1}+$ pupuk organik kotoran ayam $5 \mathrm{t} \mathrm{ha}^{-1}, \mathrm{P} 6=$ pupuk organik kotoran kambing $10 \mathrm{tha}^{-1}+$ pupuk organik kotoran ayam $10 \mathrm{t} \mathrm{ha}^{-1}$. Hasil penelitian menunjukkan dosis pupuk organik kotoran kambing dan pupuk organik kotoran ayam berpengaruh terhadap tinggi tanaman bawang merah pada umur 30 HST dan 45 HST. Pupuk organik kotoran ayam $20 \mathrm{t} \mathrm{ha}^{-1}$ dan kombinasi pupuk organik kotoran kambing $10 \mathrm{t} \mathrm{ha}^{-1}+$ pupuk organik kotoran ayam $10 \mathrm{t} \mathrm{ha}^{-1}$ memberikan pengaruh lebih baik terhadap tinggi tanaman pada umur 30 HST dan 45 HST dibanding tanpa pupuk organik.
\end{abstract}

Kata Kunci : Hasil, Jenis dan Dosis Pupuk Organik, Pemupukan, Pertumbuhan

\begin{abstract}
One of the efforts to increase the yield of shallots through cultivation techniques is fertilization. Fertilization is the provision of fertilizers to increase the supply of nutrients needed by plants to increase yield and quality of crop yields. The purpose of this study was to obtain the combination of types and dosages that had the best effect on the growth and yield of shallot (Allium ascalonicum L.). The research was carried out from February to April 2021 at the experimental garden of the Faculty of Agriculture Siliwangi University, Mugarsari Village Tamansari District, Tasikmalaya City at an altitude of 374 meters above sea level. This study used an experimental method with a Randomized Block Design (RCBD) consisting of 7 treatments and repeated 4 times, namely, P0 =
\end{abstract}


control (without organic fertilizer), $\mathrm{P} 1=$ goat manure organic fertilizer $10 \mathrm{t} \mathrm{ha}^{-1}, \mathrm{P} 2=$ chicken manure organic fertilizer $10 \mathrm{tha}^{-1}, \mathrm{P} 3=$ goat manure organic fertilizer $20 \mathrm{t} \mathrm{ha}^{-1}, \mathrm{P} 4=$ chicken manure organic fertilizer $20 \mathrm{t} \mathrm{ha}^{-1}, \mathrm{P} 5=$ goat manure organic fertilizer $5 \mathrm{t} \mathrm{ha}^{-1}+$ chicken manure organic fertilizer $5 \mathrm{t} \mathrm{ha}^{-1}, \mathrm{P} 6=$ goat manure organic fertilizer $10 \mathrm{t} \mathrm{ha}^{-1}+$ chicken manure organic fertilizer 10 $\mathrm{t} \mathrm{ha}^{-1}$. The results showed that the organic fertilizer of goats and chickens had an effect on plant height at the age of 30 DAP and 45 DAP. The organic fertilizer of chicken manure 20 tons/ha and the combination of goat manure 10 tons/ha + chicken manure $10 \mathrm{t} \mathrm{ha}^{-1}$ tended to have a better effect on plant height at 30 DAP and 45 DAP compared no organic fertilizer.

Keywords: Fertilization, Growth, Type and Dose of Organic Fertilizer, Yield

\section{PENDAHULUAN}

Bawang merah (Allium ascalonicum L.) merupakan salah satu komoditas hortikultura yang dapat digunakan sebagai bahan baku industri makanan, penyedap masakan, obatobatan dan banyak disukai karena rasa dan aromanya yang khas. Bawang merah juga merupakan sumber vitamin B, C, Fosfor, Kalium, dan Mineral (Priyantono et al, 2013). Bawang merah adalah salah satu komoditas sayuran yang menjadi unggulan sejak lama dan telah diusahakan oleh para petani secara intensif.

Produksi bawang merah pada tahun 2019 yaitu sebesar 1,58 juta ton, dibanding pada tahun 2018 sebesar 1,50 juta ton produksinya meningkat sebesar 80 ribu ton (Badan Pusat Statistik dan Direktorat Jenderal Hortikultura 2019). Konsumsi bawang merah penduduk di Indonesia rata-rata mencapai 2,56 $\mathrm{kg} / \mathrm{kapita} /$ tahun. Rata-rata produktivitas tanaman bawang merah di Indonesia pada tahun 2017 adalah 9,31 ton ha-1, tahun 2018 adalah 9,59 ton ha ${ }^{-1}$ dan pada tahun 2019 adalah 9,93 ton ha ${ }^{-1}$ (Badan Pusat Statistik dan Direktorat Jenderal Hortikultura, 2019). Produktivitas bawang merah di Indonesia saat ini masih tergolong rendah yaitu masih pada kisaran 9 ton $\mathrm{ha}^{-1}$, padahal potensinya dapat mencapai sebesar 17 ton ha ${ }^{-1}$ (Ciptady, 2015).

Salah satu cara untuk meningkatkan hasil bawang merah dengan teknik budidaya adalah melakukan pemupukan. Pemupukan merupakan pemberian pupuk guna menambah persediaan unsur hara yang dibutuhkan oleh tanaman dalam meningkatkan produksi dan mutu hasil tanaman yang dihasilkan. Sekarang ini para petani cenderung banyak menggunakan pupuk kimia secara berlebihan dan terus menerus. Pemakaian pupuk kimia yang relatif tinggi dan terus-menerus ini dapat mengakibatkan dampak buruk pada lingkungan tanah, sehingga dapat menurunkan produktivitas lahan.

Penggunaan pupuk organik ini dapat menjaga keseimbangan lahan serta dapat meningkatkan produktivitas lahan juga mengurangi dampak lingkungan pada tanah. Menurut Sutanto (2006), pemakaian pupuk kimia yang berlebihan dan berulang-ulang dapat mengakibatkan ekosistem biologi tanah menjadi tidak seimbang, sehingga tujuan utama dilakukan pemupukan untuk mencukupkan unsur hara di dalam tanah justru tidak tercapai.

Pertanian organik menjadi sangat menarik perhatian untuk mengubah pola hidup lama yang menggunakan bahan kimia dalam budidaya pertanian menjadi pola hidup sehat ramah lingkungan. Pemberian pupuk organik ke pada tanah dapat mempengaruhi serta memperbaiki sifat-sifat tanah baik fisik, biologi maupun kimia tanah (Pranata, 2010).

Pupuk organik ini bisa berasal dari pupuk sampah pasar, pupuk kandang maupun dari limbah industry yang tidak berbahaya. Pupuk kandang merupakan pupuk yang terdiri atas bahan organik yang berasal dari kotoran hewan yang telah melalui proses rekayasa, dapat berbentuk padat atau cair yang dapat 
digunakan untuk mensuplai bahan organik yang berfungsi dalam memperbaiki sifat fisik, biologi, dan kimia tanah. Pupuk kandang ini mengandung unsur hara yang cukup lengkap, baik unsur hara makro serta mikro. Kondisi ini tidak dimiliki pada pupuk kimia. Pupuk kandang mengandung asam-asam organik, antara lain asam fulfat, asam humat, hormon dan enzim yang tidak dimiliki pada pupuk kimia, tentunya ini yang sangat bermanfaat baik bagi tanaman, lingkungan juga mikroorganisme di tanah.

Pemberian bahan organik bisa dilakukan dengan pemberian pupuk kandang, pupuk hijau dan kompos, selain itu juga bisa digunakan menjadi pupuk organik cara fermentasi atau disingkat porasi. Pupuk organik ini tidak sama dengan kompos, namun demikian keduanya merupakan sumber dari bahan organik. Kompos dibuat melalui proses atau hasil penguraian bahan organik yang hanya menggunakan mikroorganisme yang ada di alam, membutuhkan cukup waktu yang relatif lama (1 sampai dengan 3 bulan) untuk dapat diaplikasikan pada tanaman, sedangkan pupuk organik yang merupakan hasil dari fermentasi bahan organik dengan bantuan atau penambahan mikroorganisme dari luar yang membantu mempercepat proses penguraian sehingga hanya butuh waktu yang relatif cukup singkat dibanding dengan pembuatan pupuk kompos. Hal ini sesuai dengan pendapat Priyadi (2017) bahwa pembuatan pupuk organik yang menggunakan pupuk hayati MBio dapat memfermentasi bahan organik dalam waktu yang relative cukup singkat. Pemberian pupuk hayati M-Bio dalam bentuk pupuk organik kotoran kambing pada dosis 20 $\mathrm{t} \mathrm{ha}^{-1}$ dapat memberikan hasil yang yaitu baik pada volume akar, bobot akar gada, jumlah daun dan bobot segar daun. Menurut Priyadi, (2017) bahwa pada perlakuan takaran pupuk organik kotoran ayam sebanyak $10 \mathrm{t} \mathrm{ha}^{-1}$ dapat memberikan hasil selada kultivar Crispo sebanyak 3.799,25 $\mathrm{g} \mathrm{plot}^{-1}$ atau setara 15,20 t $\mathrm{ha}^{-1}$.
Penggunaan pupuk organik yang berasal dari kotoran ternak sangat bermanfaat terhadap pertumbuhan dan hasil tanaman, selain itu penggunaan pupuk organik juga lebih aman dan ramah lingkungan. Berdasarkan uraian di atas, perlu dilakukan penelitian tentang aplikasi berbagai dosis pupuk organik kotoran kambing dan kotoran ayam broiler pada hasil tanaman bawang merah (Allium ascalonicum L.).

\section{BAHAN DAN METODE}

\section{Waktu dan Tempat Penelitian}

Penelitian dilaksanakan pada bulan Februari sampai bulan April 2021, di Kampus Universitas Siliwangi, Lahan Percobaan Fakultas, Kelurahan Mugarsari, Kecamatan Tamansari, Kota Tasikmalaya dengan ketinggian 374 meter dpl.

\section{Alat dan Bahan}

Alat-alat yang digunakan adalah : cangkul, ember plastik, timbangan, gelas ukur, terpal atau plastik besar untuk fermentasi, alat tulis, penggaris, kamera.

Bahan-bahan yang digunakan dalam penelitian ini yaitu : umbi bibit bawang merah varietas Bima Brebes, lahan, kotoran kambing, kotoran ayam broiler, air, tanah, dedak, gula merah, pupuk hayati M-Bio sebagai sumber mikroba, dan fungisida.

\section{Metode Penelitian}

Penelitian ini menggunakan metode eksperimen dengan Rancangan Acak Kelompok (RAK) yang terdiri dari 7 perlakuan dan pengulangan sebanyak 4 kali. Faktor perlakuannya yaitu sebagai berikut :

P0 : tanpa pupuk organik

P1 : pupuk organik kotoran kambing $10 \mathrm{tha}^{-1}$ P2 : pupuk organik kotoran ayam $10 \mathrm{t} \mathrm{ha}^{-1}$

P3 : pupuk organik kambing $20 \mathrm{tha}^{-1}$

P4 : pupuk organik kotoran ayam $20 \mathrm{tha}^{-1}$

P5: pupuk organik kotoran kambing $5 \mathrm{t} \mathrm{ha}^{-1}+$ pupuk organik kotoran ayam $5 \mathrm{t} \mathrm{ha}^{-1}$

P6 : pupuk organik kotoran kambing $10 \mathrm{t} \mathrm{ha}^{-1}$ + pupuk organik kotoran ayam $10 \mathrm{t} \mathrm{ha}^{-1}$ 
Rancangan analisis menggunakan uji F. Pengambilan keputusan berdasarkan pada nilai $\mathrm{F}$ hitung dibandingkan dengan nilai $\mathrm{F}$ tabel. Jika $\mathrm{F}$ hitung $\leq \mathrm{F}$ tabel maka tidak ada pengaruh perlakuan. Jika $\mathrm{F}$ hitung $>\mathrm{F}$ tabel maka terdapat pengaruh perlakuan yang diteliti. Jika terdapat pengaruh nyata, langkah berikutnya dilakukan uji lanjut yaitu dengan menggunakan uji jarak berganda Duncan pada taraf nyata 5\% dengan rumus sebagai berikut:

$$
\mathrm{LSR}=\operatorname{SSR}(\alpha \cdot d b g \cdot p) \cdot S_{X}
$$

$$
S \bar{x}=\sqrt{\frac{\text { KT Galat }}{\mathrm{r}}}
$$

Sumber : (Gomez dan Gomez 2010).

Variabel yang diamati yaitu meliputi tinggi tanaman, jumlah daun, jumlah umbi per rumpun, diameter umbi, bobot umbi per rumpun, bobot umbi per petak dan per hektar.

1. Pembuatan pupuk organik kotoran kambing dan kotoran ayam sebagai berikut :

a. Siapkan bahan organik (kotoran kambing dan kotoran ayam) masing-masing sebanyak $30 \mathrm{~kg}$, kemudian masingmasing bahan tersebut dicampurkan dedak secara terpisah.

b. Pupuk hayati M-Bio, gula merah (50 gram) dilarutkan ke dalam air dengan konsentrasi $10 \mathrm{ml} \mathrm{L}^{-1}$ air lalu disiramkan pada masing-masing adonan secara merata, sampai mencapai kadar air adonan mencapai 50\% (apabila pada saat adonan dikepal, air tidak menetes dari adonan dan apabila adonan dilepaskan adonan menjadi mekar).

c. Adonan diratakan pada ketinggian 10 sampai $40 \mathrm{~cm}$, lalu ditutup menggunakan plastik/terpal dan dibiarkan selama 14 hari. Selanjutnya adonan dibolak balik setiap 2 hari sekali.

d. Setelah 14 hari mengalami fermentasi, maka dihasilkan pupuk organik kotoran kambing dan kotoran ayam yang dingin, kering, dan memiliki aroma yang khas serta siap untuk diaplikasikan.

2. Pemupukan

Aplikasi pupuk dilakukan 1 kali yaitu pada satu minggu sebelum tanam dengan menggunakan pupuk organik kotoran kambing dan kotoran ayam sesuai dosis yang telah ditentukan. Pupuk organik kotoran kambing dan kotoran ayam ditimbang menurut dosis perlakuan. Setiap petak akan ditabur dengan pupuk organik sesuai perlakuan, setelah itu diratakan dengan cangkul dan sedikit digemburkan supaya tercampur rata.

\section{HASIL DAN PEMBAHASAN}

\section{Tinggi Tanaman}

Hasil analisis statistik menunjukkan bahwa kombinasi jenis dan dosis pupuk organik berpengaruh tidak nyata terhadap tinggi tanaman bawang merah pada umur 15 HST, namun berpengaruh nyata tehadap tinggi bawang merah pada umur 30 HST dan 45 HST seperti disajikan pada Tabel 1.

Hal ini diduga karena pada saat tanaman berumur 15 hari setelah tanam unsur hara yang ada pada media tanam belum bisa diserap secara optimal oleh tanaman pada awal pertumbuhan. Hal ini terjadi karena pupuk yang diaplikasikan masih lambat tersedia bagi tanaman, sehingga oleh tanaman belum memberikan respon yang berbeda nyata.

Pada umur 30 hari setelah tanam, perlakuan P4 (pupuk organik kotoran ayam $20 \mathrm{t} \mathrm{ha}^{-1}$ ), P5 (pupuk organik kotoran kambing $5 \mathrm{t} \mathrm{ha}^{-1}+$ pupuk organik kotoran ayam $5 \mathrm{t} \mathrm{ha}^{-1}$ ), P6 (pupuk organik kotoran kambing $10 \mathrm{t} \mathrm{ha}^{-1}+$ pupuk organik kotoran ayam $10 \mathrm{t} \mathrm{ha}^{-1}$ ), P2 (pupuk organik kotoran ayam $10 \mathrm{t} \mathrm{ha}^{-1}$ ) dan P1 (pupuk organik kotoran kambing $10 \mathrm{t} \mathrm{ha}^{-1}$ ) berbeda nyata dengan P0 (tanpa pupuk organik) dan P3 (pupuk organik kotoran kambing $20 \mathrm{t} \mathrm{ha}^{-1}$ ). 
Hal ini diduga karena pupuk organik tersebut sudah terurai dengan baik sehingga tanah menjadi lebih gembur dan pertumbuhan tanaman menjadi lebih baik.

Tabel 1. Pengaruh kombinasi jenis dan dosis pupuk organik terhadap tinggi bawang merah 15 , 30,45 HST

\begin{tabular}{|c|c|c|c|}
\hline \multirow[t]{2}{*}{ Perlakuan } & \multicolumn{3}{|c|}{ Tinggi tanaman $(\mathrm{cm})$} \\
\hline & $15 \mathrm{HST}$ & $30 \mathrm{HST}$ & $45 \mathrm{HST}$ \\
\hline$\overline{\mathrm{P} 0}$ : Tanpa pupuk organik & $16,99 \mathrm{a}$ & $24,95 \mathrm{a}$ & $33,65 \mathrm{a}$ \\
\hline P1 : Pupuk organik kotoran kambing $\left(10 \mathrm{t} \mathrm{ha}^{-1}\right)$ & $18,05 \mathrm{a}$ & $27,32 \mathrm{abc}$ & $37,65 \mathrm{~b}$ \\
\hline P2 : Pupuk organik kotoran ayam $\left(10 \mathrm{t} \mathrm{ha}^{-1}\right)$ & $17,53 \mathrm{a}$ & $28,21 \mathrm{bc}$ & $38,54 \mathrm{~b}$ \\
\hline P3 : Pupuk organik kotoran kambing $\left(20 \mathrm{t} \mathrm{ha}^{-1}\right)$ & $18,32 \mathrm{a}$ & $27,08 \mathrm{ab}$ & $37,79 \mathrm{~b}$ \\
\hline P4 : Pupuk organik kotoran ayam $\left(20 \mathrm{t} \mathrm{ha}^{-1}\right)$ & $18,37 \mathrm{a}$ & $29,81 \mathrm{c}$ & $37,82 \mathrm{~b}$ \\
\hline $\begin{array}{l}\text { P5 : Pupuk organik kotoran kambing }+ \text { pupuk organik } \\
\quad \text { kotoran ayam }\left(5 \mathrm{t} \mathrm{ha}^{-1}+5 \mathrm{tha}^{-1}\right)\end{array}$ & $18,47 \mathrm{a}$ & $29,39 \mathrm{bc}$ & $37,90 \mathrm{~b}$ \\
\hline $\begin{array}{l}\text { P6 : Pupuk organik kotoran kambing + pupuk organik } \\
\quad \text { kotoran ayam }\left(10 \mathrm{tha}^{-1}+10 \mathrm{t} \mathrm{ha}^{-1}\right)\end{array}$ & 18,36 a & $28,07 \mathrm{bc}$ & $40,01 \mathrm{~b}$ \\
\hline
\end{tabular}

Pada umur 45 hari setelah tanam perlakuan jenis dan dosis pupuk organik hanya berbeda nyata dengan perlakuan tanpa diberi pupuk organik, sedangkan antara perlakuan pemberian jenis dan dosis pupuk organik berbeda tidak nyata. Hal tersebut diduga karena bahan organik bisa menyimpan air, ketersediaan unsur hara dapat meningkatkan aktivitas mikroorganisme di pada tanah untuk membantu kesuburan tanah sehingga bahan organik yang diberikan bisa meningkatkan tinggi daun bawang merah. Begitu juga dengan unsur hara $\mathrm{N}$ dan unsur hara yang lain pada bahan organik dilepaskan secara perlahan-lahan melalui proses mineralisasi sehingga akan sangat membantu untuk kesuburan tanah. Hal ini sejalan dengan Sahetapy et al, (2017) yang mengemukakan bahwa aplikasi bahan organik mampu meningkatkan konsentrasi hara dalam tanah, penyimpanan, porositas, dan penyediaan air serta aerasi dan temperatur tanah.

\section{Jumlah Daun}

Hasil analisis statistik menunjukkan bahwa kombinasi jenis dan dosis pupuk organik pada tanaman bawang merah berpengaruh tidak nyata terhadap jumlah daun bawang merah pada semua umur pengamatan, seperti disajikan pada Tabel 2 .

Tabel 2. Pengaruh kombinasi dan dosis pupuk organik terhadap jumlah daun bawang merah 15 , 30,45 HST

\begin{tabular}{|c|c|c|c|c|}
\hline \multirow{2}{*}{\multicolumn{2}{|c|}{ Perlakuan }} & \multicolumn{3}{|c|}{ Jumlah daun (helai) } \\
\hline & & $15 \mathrm{HST}$ & $30 \mathrm{HST}$ & 45 HST \\
\hline & : Tanpa pupuk organik & $12,12 \mathrm{a}$ & $18,65 \mathrm{a}$ & $33,37 \mathrm{a}$ \\
\hline P1 & : Pupuk organik kotoran kambing $\left(10 \mathrm{t} \mathrm{ha}^{-1}\right)$ & $12,65 \mathrm{a}$ & $20,37 \mathrm{a}$ & 34,96 a \\
\hline $\mathrm{P} 2$ & : Pupuk organik kotoran ayam $\left(10 \mathrm{t} \mathrm{ha}^{-1}\right)$ & $12,56 \mathrm{a}$ & $19,71 \mathrm{a}$ & 34,84 a \\
\hline P3 & : Pupuk organik kotoran kambing $\left(20 \mathrm{t} \mathrm{ha}^{-1}\right)$ & $13,31 \mathrm{a}$ & $21,15 \mathrm{a}$ & $35,12 \mathrm{a}$ \\
\hline P4 & : Pupuk organik kotoran ayam $\left(20 \mathrm{t} \mathrm{ha}^{-1}\right)$ & $13,06 \mathrm{a}$ & $20,40 \mathrm{a}$ & 33,96 a \\
\hline & $\begin{array}{l}\text { : Pupuk organik kotoran kambing }+ \text { pupuk organik } \\
\text { kotoran ayam }\left(5 \mathrm{t} \mathrm{ha}^{-1}+5 \mathrm{tha}^{-1}\right)\end{array}$ & $12,15 \mathrm{a}$ & $20,68 \mathrm{a}$ & $33,84 \mathrm{a}$ \\
\hline P6 & $\begin{array}{l}\text { : Pupuk organik kotoran kambing }+ \text { pupuk organic } \\
\text { kotoran ayam }\left(10 \mathrm{t} \mathrm{ha}^{-1}+10 \mathrm{t} \mathrm{ha}^{-1}\right)\end{array}$ & $12,59 \mathrm{a}$ & $20,62 \mathrm{a}$ & $34,37 \mathrm{a}$ \\
\hline
\end{tabular}


Pada Tabel 2 diketahui bahwa pemberian pupuk organik kotoran kambing dan pupuk organik kotoran ayam berbeda tidak nyata terhadap jumlah daun (helai) pada saat tanaman berumur 15, 30 dan 45 HST. Hal ini diduga karena dipengaruhi oleh sifat genetik tanaman tersebut serta faktor lingkungan. Menurut Sumarni dan Rosliani (2006) dalam Putrasamedja et al, (2012), bahwa faktor genetik dan faktor lingkungan turut menentukan dalam pembentukan daun serta jumlah daun. Dilihat dari Tabel di atas ada kecenderungan bahwa pupuk organik kotoran kambing $20 \mathrm{t} \mathrm{ha}^{-1}$ memberikan nilai rata-rata tertinggi dari semua perlakuan. Hal ini diduga karena pupuk organik kotoran kambing dengan dosis $20 \mathrm{t} \mathrm{ha}^{-1}$ bisa memenuhi kebutuhan unsur hara tanaman sehingga menghasilkan jumlah daun yang lebih baik dibanding dengan perlakuan lainnya.

Berdasarkan hasil penelitian dapat diketahui bahwa tinggi rendahnya pertumbuhan dan hasil tanaman dapat dipengaruhi oleh dua faktor yaitu faktor internal dan faktor eksternal. Faktor internal adalah faktor yang dipengaruhi oleh sifat genetik atau sifat turunan seperti usia tanaman, daya hasil, morfologi tanaman, kapasitas menyimpan cadangan makanan, ketahanan terhadap penyakit dan lain-lain. Sedangkan faktor eksternal merupakan faktor lingkungan seperti iklim, tanah, dan faktor biotik.

\section{Jumlah Umbi per Rumpun}

Hasil analisis statistik menunjukkan bahwa kombinasi jenis dan dosis pupuk organik berpengaruh tidak nyata terhadap jumlah, seperti disajikan pada Tabel 3.

Tabel 3. Pengaruh kombinasi dan dosis pupuk organik terhadap jumlah umbi per rumpun

\begin{tabular}{lc}
\hline Perlakuan & Jumlah umbi (buah) \\
\hline P0 : Tanpa pupuk organik & $7,25 \mathrm{a}$ \\
P1 : Pupuk organik kotoran kambing $\left(10 \mathrm{tha}^{-1}\right)$ & $6,71 \mathrm{a}$ \\
P2 : Pupuk organik kotoran ayam $\left(10 \mathrm{tha}^{-1}\right)$ & $7,12 \mathrm{a}$ \\
P3 : Pupuk organik kotoran kambing $\left(20 \mathrm{tha}^{-1}\right)$ & $7,56 \mathrm{a}$ \\
P4 : Pupuk organik kotoran ayam $\left(20 \mathrm{tha}^{-1}\right)$ & $6,65 \mathrm{a}$ \\
P5 : Pupuk organik kotoran kambing + pupuk organik kotoran ayam & $7,93 \mathrm{a}$ \\
$\quad\left(5 \mathrm{tha}^{-1}+5 \mathrm{tha}^{-1}\right)$ & \\
P6 : Pupuk organik kotoran kambing + pupuk organik kotoran ayam & $7,37 \mathrm{a}$ \\
$\quad\left(10 \mathrm{tha}^{-1}+10 \mathrm{tha}^{-1}\right)$ & \\
\hline
\end{tabular}

Keterangan : Angka-angka yang diikuti dengan huruf yang sama pada kolom yang sama menunjukkan tidak berbeda nyata menurut Uji Jarak Berganda Duncan pada taraf nyata 5\%.

Pada Tabel 3 menunjukkan bahwa pemberian pupuk organik kotoran kambing dan pupuk organik kotoran ayam pada setiap perlakuan tidak berbeda nyata terhadap jumlah umbi bawang merah. Hal ini diduga jumlah umbi per rumpun lebih dominan dipengaruhi oleh faktor genetik. Oleh karena itu sifat genetik tanaman dalam hal ini juga berperan dalam masa pertumbuhan tanaman hingga masa produksi. Hal ini sesuai dengan pendapat Ambarwati dan Yudono (2012) bahwa hasil bawang merah dipengaruhi oleh varietas. Menurut Sumarni et al, (2013), setiap varietas mempunyai potensi hasil serta karakter yang berbeda-beda. Hal ini disebabkan karena pembentukan umbi dipengaruhi oleh kemampuan tanaman dalam mendistribusikan hasil fotosintat ke bagian daun dan umbi.

Menurut Azmi et al, (2016) perbedaan hasil jumlah umbi berbagai varietas bisa disebabkan karena fenotipik tanaman ditentukan oleh interaksi antara genetik (varietas) dan lingkungan. Varietas yang berdaya hasil tinggi disuatu tempat belum 
tentu memberikan hasil yang tinggi di tempat lain.

\section{Diameter Umbi}

Hasil analisis statistik menunjukkan bahwa kombinasi jenis dan dosis pupuk organik berpengaruh tidak nyata terhadap diameter umbi bawang merah, seperti disajikan pada Tabel 4.

Tabel 4. Pengaruh kombinasi dan dosis pupuk organik terhadap diameter umbi bawang merah

\begin{tabular}{|c|c|}
\hline Perlakuan & Diameter umbi $(\mathrm{mm})$ \\
\hline P0 : Tanpa pupuk organik & 24,59 a \\
\hline P1 : Pupuk organik kotoran kambing $(10 \mathrm{c})$ & $26,23 \mathrm{a}$ \\
\hline P2 : Pupuk organik kotoran ayam $\left(10 \mathrm{t} \mathrm{ha}^{-1}\right)$ & $27,73 \mathrm{a}$ \\
\hline P3 : Pupuk organik kotoran kambing $\left(20 \mathrm{t} \mathrm{ha}^{-1}\right)$ & $25,90 \mathrm{a}$ \\
\hline P4 : Pupuk organik kotoran ayam $\left(20 \mathrm{t} \mathrm{ha}^{-1}\right)$ & $27,23 \mathrm{a}$ \\
\hline $\begin{array}{l}\text { P5 : Pupuk organik kotoran kambing }+ \text { pupuk organik kotoran ayam } \\
\left(5 \mathrm{t} \mathrm{ha}^{-1}+5 \mathrm{t} \mathrm{ha}^{-1}\right)\end{array}$ & $27,15 \mathrm{a}$ \\
\hline $\begin{array}{l}\text { P6 : Pupuk organik kotoran kambing }+ \text { pupuk organik kotoran ayam } \\
\left(10 \mathrm{t} \mathrm{ha}^{-1}+10 \mathrm{t} \mathrm{ha}^{-1}\right)\end{array}$ & $27,69 \mathrm{a}$ \\
\hline
\end{tabular}

Pada Tabel 4 diketahui bahwa pemberian pupuk organik kotoran kambing dan pupuk organik kotoran ayam pada setiap perlakuan berpengaruh tidak nyata terhadap diameter umbi bawang merah. Namun demikian, ada kecenderungan diameter umbi per rumpun lebih baik yang diberi pupuk organik kotoran ayam dengan dosis $10 \mathrm{t} \mathrm{ha}^{-1}$ dibanding tanpa pupuk organik. Hal ini diduga karena tanaman bawang merah mampu memanfaatkan dan menyerap hara tersebut serta menghasilkan fotosintat yang digunakan untuk pertumbuhannya termasuk pembentukan umbi bawang merah.

Sejalan dengan pendapat Putrasamedja et $a l$, (2012) selain lingkungan, besar umbi dipengaruhi oleh faktor genetik. Menurut Azmi et al, (2011) perbedaan ukuran pada umbi maka diameter umbi akan meningkat seiring dengan makin besarnya umbi benih yang digunakan, umbi yang berukuran besar tumbuh lebih baik dan menghasilkan daun-daun yang lebih panjang, luas daun lebih besar, sehingga dihasilkan jumlah umbi pertanaman dan total hasil yang tinggi.
Menurut Herwanda et al, (2017) pertumbuhan suatu tanaman dipengaruhi oleh faktor genetik atau pewarisan sifat tanaman dan faktor lingkungan yang meliputi air, kelembaban udara, suhu, dan intensitas cahaya matahari.

\section{Bobot Umbi per Rumpun}

Hasil analisis statistik menunjukkan bahwa kombinasi jenis dan dosis pupuk organik berpengaruh tidak nyata terhadap bobot umbi per rumpun bawang merah, seperti disajikan pada Tabel 5 .

Pada Tabel 5 menunjukkan bahwa pemberian pupuk organik kotoran kambing dan pupuk organik kotoran ayam pada setiap perlakuan tidak berbeda nyata terhadap bobot umbi per rumpun tanaman bawang merah. Hal ini terjadi dimungkinkan bobot umbi tanaman lebih dipengaruhi oleh faktor genetik tanaman. Hal ini sejalan dengan Sumarni et al, (2012) dalam Indriyana at al, (2020) yang menyatakan bahwa jumlah umbi lebih banyak ditentukan oleh faktor genetik dari pada faktor lingkungan serta pemupukan. 
Tabel 5. Pengaruh kombinasi dan dosis pupuk organik terhadap bobot umbi bawang merah.

\begin{tabular}{lc}
\hline Perlakuan & Bobot umbi per rumpun $(\mathrm{g})$ \\
\hline P0 : Tanpa pupuk organik & $53,75 \mathrm{a}$ \\
P1 : Pupuk organik kotoran kambing $\left(10 \mathrm{tha}^{-1}\right)$ & $57,12 \mathrm{a}$ \\
P2 : Pupuk organik kotoran ayam $\left(10 \mathrm{th}^{-1}\right)$ & $65,31 \mathrm{a}$ \\
P3 : Pupuk organik kotoran kambing $\left(20 \mathrm{tha}^{-1}\right)$ & $60,06 \mathrm{a}$ \\
P4 : Pupuk organik kotoran ayam $\left(20 \mathrm{tha}^{-1}\right)$ & $60,96 \mathrm{a}$ \\
P5 : Pupuk organik kotoran kambing + pupuk organik kotoran ayam & $62,09 \mathrm{a}$ \\
$\quad\left(5 \mathrm{tha}^{-1}+5 \mathrm{tha}^{-1}\right)$ & \\
P6 : Pupuk organik kotoran kambing + pupuk organik kotoran ayam & $58,09 \mathrm{a}$ \\
$\quad\left(10 \mathrm{tha}^{-1}+10 \mathrm{tha}^{-1}\right)$ & \\
\hline
\end{tabular}

Keterangan : Angka-angka yang diikuti dengan huruf yang sama pada kolom yang sama menunjukkan tidak berbeda nyata menurut Uji Jarak Berganda Duncan pada taraf nyata 5\%.

Selain itu, tidak nyatanya pengaruh pupuk organik terhadap bobot umbi diduga karena kandungan hara dalam tanah dan pupuk organik tersebut belum mampu memenuhi kebutuhan hara pada tanaman bawang merah secara optimum. Menurut Napitupulu dan Winarto (2010) bahwa pada pemberian pupuk kalium pada tanah yang cukup dapat memberikan pertumbuhan bawang merah lebih baik dan menunjukkan hasil yang baik, penambahan pupuk kalium berpengaruh nyata terhadap bobot umbi per rumpun dan kalium berperan dalam proses fotosintesis serta dapat meningkatkan bobot umbi. Selain itu didukung oleh pendapat Damanik et al, (2011) bahwa kalium sangat dibutuhkan untuk proses pembentukan fotosintesis serta bisa meningkatkan berat umbi.

\section{Bobot Umbi per Petak dan per Hektar}

Hasil analisis statistik menunjukkan bahwa kombinasi jenis dan dosis pupuk organik pada tanaman bawang merah berpengaruh tidak nyata terhadap bobot umbi per petak dan per hektar bawang merah, seperti disajikan pada Tabel 6 .

Tabel 6. Pengaruh kombinasi dan dosis pupuk organik terhadap bobot umbi per petak dan per hektar bawang merah

\begin{tabular}{lcc}
\hline Perlakuan & $\begin{array}{c}\text { Bobot umbi } \\
\text { per petak }(\mathrm{kg})\end{array}$ & $\begin{array}{c}\text { Bobot umbi } \\
\text { per hektar }\left(\mathrm{t} \mathrm{ha}^{-1}\right)\end{array}$ \\
\hline P0 : Tanpa pupuk organik & $1,36 \mathrm{a}$ & 7,25 \\
P1 : Pupuk organik kotoran kambing $\left(10 \mathrm{t} \mathrm{ha}^{-1}\right)$ & $1,53 \mathrm{a}$ & 8,16 \\
P2 : Pupuk organik kotoran ayam $\left(10 \mathrm{t} \mathrm{ha}^{-1}\right)$ & $1,77 \mathrm{a}$ & 9,44 \\
P3 : Pupuk organik kotoran kambing $\left(20 \mathrm{t} \mathrm{ha}^{-1}\right)$ & $1,66 \mathrm{a}$ & 8,85 \\
P4 : Pupuk organik kotoran ayam $\left(20 \mathrm{t} \mathrm{ha}^{-1}\right)$ & $1,73 \mathrm{a}$ & 9,23 \\
P5 : Pupuk organik kotoran kambing + pupuk organik kotoran & $1,64 \mathrm{a}$ & 8,75 \\
$\quad$ ayam (5 $\left.\mathrm{t} \mathrm{ha}^{-1}+5 \mathrm{t} \mathrm{ha}^{-1}\right)$ & & 8,64 \\
P6 : Pupuk organik kotoran kambing + pupuk organik kotoran & $1,61 \mathrm{a}$ & \\
$\quad$ ayam $\left(10 \mathrm{tha}^{-1}+10 \mathrm{t} \mathrm{ha}^{-1}\right)$ & &
\end{tabular}

Keterangan : Angka-angka yang diikuti dengan huruf yang sama pada kolom yang sama menunjukkan tidak berbeda nyata menurut Uji Jarak Berganda Duncan pada taraf nyata 5\%.

Pada Tabel 6 menunjukkan bahwa pemberian pupuk organik kotoran kambing dan pupuk organik kotoran ayam pada setiap perlakuan tidak berbeda nyata terhadap bobot umbi per petak dan per hektar bawang merah. Hal ini terjadi kemungkinan dikarenakan faktor internal dan eksternal tanaman yang lebih lebih. Sejalan dengan Sugiyarto et al, (2013) menyatakan bahwa hasil bobot umbi bawang merah dapat 
dipengaruhi oleh sifat dominan genetis dan lingkungannya.

Penyebab lain diduga karena kandungan hara dalam tanah dan pupuk organik belum mampu memenuhi kebutuhan tanaman bawang merah secara optimum. Sesuai dengan pendapat (Sumarni et al., 2013) rendahnya hasil umbi yang diperoleh dalam tanah dengan status kalium tanah rendah disebabkan karena kekurangan hara kalium yang mempunyai peran penting pada translokasi dan penyimpanan asimilat, peningkatan ukuran jumlah dan hasil umbi per tanaman. Unsur hara kalium berperan sebagai aktivator enzim-enzim yang dapat berpengaruh langsung pada proses metabolisme yang membentuk karbohidrat.. Hal ini terjadi kemungkinan faktor internal maupun eksternal tanaman lebih dominan sehingga pupuk kandang sapi dan pupuk hayati tidak dapat memberikan perbedaan pada berat kering tanaman.

\section{SIMPULAN}

Berdasarkan hasil penelitian yang telah dilakukan, maka dapat disimpulkan sebagai berikut:

1. Dosis pupuk organik kotoran kambing dan pupuk organik kotoran ayam berpengaruh terhadap tinggi tanaman bawang merah pada umur 30 HST dan 45 HST.

2. Pupuk organik kotoran ayam $20 \mathrm{t} \mathrm{ha}^{-1}$ dan kombinasi pupuk organik kotoran kambing $10 \mathrm{t} \mathrm{ha}^{-1}+$ pupuk organik kotoran ayam $10 \mathrm{t} \mathrm{ha}^{-1}$ memberikan pengaruh lebih baik terhadap tinggi tanaman pada umur 30 HST dan 45 HST dibanding tanpa pupuk organik.

Disarankan perlu dilakukan penelitian lanjutan untuk menggunakan pupuk organik kambing dan pupuk organik ayam dengan dosis yang sama atau lebih tinggi di tempat yang berbeda. Penggunaan pupuk organik ayam dengan dosis 10-20 $\mathrm{t} \mathrm{ha}^{-1}$ disarankan ke petani dalam budidaya tanaman bawang merah.

\section{UCAPAN TERIMAKASIH}

Ucapan terimakasih kepada semua pihak yang telah membantu dalam pelaksanaan penelitian ini baik secara material dan non material.

\section{DAFTAR PUSTAKA}

Ambarwati, Erlina, and Prapto Yudono. (2012). "The Performance of Yield Stability of Shallot." Ilmu Pertanian 10(2): $1-10$.

Azmi, C, Iteu Margaret Hidayat, and Gugun Wiguna. (2011). "Pengaruh Varietas Dan Ukuran Umbi Terhadap Produktivitas Bawang Merah." Jurnal Hortikultura 21(3): 206-2013.

(2016). "Inspirasi Desain \& Cara Membuat Vertical Garden." Jurnal Hortikultura 21(3): 206-2011.

Badan Pusat Statistik dan Direktorat Jenderal Hortikultura. (2019). "Produksi Dan Produktivitas Bawang Merah, Tahun 2015- 2019." Kementerian Pertanian Republik Indonesia. https://www.pertanian.go.id/home/?sho $\mathrm{w}=$ page $\&$ act $=$ view\&id $=61$.

Ciptady. (2015). "Budidaya Bawang Merah.” In Jakarta: Penebar swadaya.

Damanik, Hasibuan, Sarifuddin, and Hanum. (2011). Kesuburan Tanah Dan Pemupukan. Medan: Univeristas Sumatra Utara Prss.

Gomez, K. A., and A.A Gomez. (2010). Prosedur Statistik Untuk Penelitian Pertanian. Depok: Universitas Indonesia.

Herwanda, Rangga, Wisnu Eko Murdiono, and Koesriharti Koesriharti. (2017). "Aplikasi Nitrogen Dan Pupuk Daun Terhadap Pertumbuhan Dan Hasil 
Tanaman Bawang Merah (Allium Cepa L. Var. Ascalonicum)." Jurnal Produksi Tanaman 5(1): 46-53.

Indriyana, A, Yafizham, and Sumarsono. (2020). "Pertumbuhan Dan Produksi Bawang Merah (Allium Ascolonicum L.) Akibat Pemberian Pupuk Kandang Sapi Dan Pupuk Hayati." J. Agro Complex 4(1): $7-15$. http://ejournal2.undip.ac.id/index.php/jo ac.

Lakitan. (2008). "Dasar-Dasar Fisiologi Tumbuhan." : 1-205.

Napitupulu, D., and L. Winarto. (2010). "Pengaruh Pemberian Pupuk N Dan K Terhadap Pertumbuhan Dan Produksi Bawang Merah." Jurnal Hortikultura 20 (1): 27-35.

Pranata. (2010). Pupuk Organik Cair Aplikasi Dan Manfaatnya. Jakarta: Agromedia Pustaka.

Priyadi, Rudi. (2017). Teknologi M-Bio Untuk Pertanian Dan Kesehatan Lingkungan. 2nd ed. Tasikmalaya: PPS Unsil Press.

Priyantono, Eko, Andi Ete, and Adrianton. (2013). "Vigor Umbi Bawang Merah ( Allium Ascallonicum L .) Varietas Palasa Dan Lembah Palu Pada Berbagai Kondisi Simpan." e-J. Agrotekbis 1(1): 8-16.

Putrasamedja, Sartono, Wiwin Setiawati, L Lukman, and Ahsol Hasyim. (2012). "Penampilan Beberapa Klon Bawang Merah Dan Hubungannya Dengan Intensitas Serangan Organisme Pengganggu Tumbuhan." Jurnal Hortikultura 22(4): 349-59.

Sahetapy, Marthinus Marcus, Jantje . Pongoh, and Wenny . Tilaar. (2017).
"Analisis Pengaruh Beberapa Dosis Pupuk Bokashi Kotoran Ayam Terhadap Pertumbuhan Dan Produksi Tiga Varietas Tomat (Lycopersicum Esculentum Miil.) Di Desa Airmadidi." Agri-Sosioekonomi Unsrat 13 (2A): 7082.

Simangunsong, Nova Lina, Ratna Rosanty Lahay, and Asil Barus. (2017). "Respon Pertumbuhan Dan Produksi Bawang Merah (Allium Ascalonicum L.) Pada Konsentrasi Air Kelapa Dan Lama Perendaman Umbi." Jurnal Agroekoteknologi Universitas Sumatera Utara 5 (1): 17-26.

Sugiyarto, Meiriani, and Jasmani Ginting. (2013). "Respons Pertumbuhan Dan Produksi Beberapa Varietas Bawang Merah (Allium Ascalonicum L.) Terhadap Berbagai Sumber Nitrogen Organik." Jurnal Online Agroekoteknologi 2 (1): 402-10.

Sumarni, Rosliani, Basuki, and Hilman. (2013). "Pengaruh Varietas, Status KTanah, Dan Dosis Pupuk Kalium Terhadap Pertumbuhan, Hasil Umbi, Dan Serapan Hara K Tanaman Bawang Merah.” Jurnal Hortikultura 22 (3): 233.

Sutanto. (2006). "Penerapan Pertanian Organik (Pemasyarakatan Dan Pengembangannya)." In Yogyakarta: Kanisius.

Suwandi. (2015). Pusat Data dan Sistem Informasi Pertanian Kementerian Pertanian Outlook Komoditas Pertanian Subsektor Hortikultura Bawang Merah. Jakarta: Pusat Data dan Sistem Informasi Pertanian Kementerian Pertanian. http://epublikasi.setjen.pertanian.go.id/. 